\title{
A 7-Level Single DC Source Cascaded H-Bridge Multilevel Inverter with a Modified DTC Scheme for Induction Motor-Based Electric Vehicle Propulsion
}

\author{
Farid Khoucha, ${ }^{1,2}$ Khoudir Marouani, ${ }^{2}$ Mohamed Benbouzid, ${ }^{1}$ \\ Abdelaziz Kheloui, ${ }^{2}$ and Abdeslam Mamoune ${ }^{1}$ \\ ${ }^{1}$ University of Brest, EA 4325 LBMS, Kergoat Street, CS 93837, 29238 Brest Cedex 03, France \\ ${ }^{2}$ Ecole Militaire Polytechnique, UER ELT, 16111 Algiers, Algeria \\ Correspondence should be addressed to Mohamed Benbouzid; mohamed.benbouzid@univ-brest.fr
}

Received 1 September 2012; Revised 15 January 2013; Accepted 16 January 2013

Academic Editor: Lingyang Song

Copyright (C) 2013 Farid Khoucha et al. This is an open access article distributed under the Creative Commons Attribution License, which permits unrestricted use, distribution, and reproduction in any medium, provided the original work is properly cited.

\begin{abstract}
This paper presents a new hybrid cascaded H-bridge multilevel inverter motor drive DTC scheme for electric vehicles where each phase of the inverter can be implemented using a single DC source. Traditionally, each phase of the inverter requires $n$ DC source for $2 n+1$ output voltage levels. In this paper, a scheme is proposed that allows the use of a single DC source as the first DC source which would be available from batteries or fuel cells, with the remaining $(n-1)$ DC sources being capacitors. This scheme can simultaneously maintain the capacitors of DC voltage level and produce a nearly sinusoidal output voltage due to its high number of output levels. In this context, high performances and efficient torque and flux control are obtained, enabling a DTC solution for hybrid multilevel inverter powered induction motor drives intended for electric vehicle propulsion. Simulations and experiments show that the proposed multilevel inverter and control scheme are effective and very attractive for embedded systems such as automotive applications.
\end{abstract}

\section{Introduction}

Currently, automotive applications such as EV's seem to constitute an increasingly effective alternative to conventional vehicles, allowing vehicle manufacturers to fulfill users requirements (dynamic performances and fuel consumption) and environmental constraints (pollutant emissions reduction) [1].

The electric propulsion system is the heart of EV. It consists of the motor drive, transmission device, and wheels. In fact, the motor drive, comprising the electric motor, the power converter, and the electronic controller, is the core of the EV propulsion system. The motor drive is configured to respond to a torque demand set by the driver [2].

The induction motor seems to be a very interesting solution for EV's propulsion. FOC and DTC have emerged as the standard industrial solutions to achieve high dynamic performance [3-5]. However some drawbacks of both methods have motivated important research efforts in the last decades. Particularly for DTC, the high torque ripple and the variable switching frequency introduced by the hysteresis comparators have been extensively addressed $[6,7]$. In addition, several contributions that combine DTC principles together with PWM and SVM have been reported to correct these problems. This approach is based on the load angle control, from which a voltage reference vector is computed which is finally modulated by the inverter [8]. Although one major feature of classic DTC is the absence of modulators and linear controllers, this approach has shown significant improvements and achieves similar dynamic performance.

On the other hand, power converter technology is continuously developing, and cascaded multilevel inverters have become a very attractive solution for EV applications, due to its modular structure, higher voltage capability, reduced common mode voltages, near sinusoidal outputs, and smaller or even no output filter [9-12]. In general, cascaded multilevel inverter may be classified in two groups. 
The first one refers to the amplitude of isolated DC sources devoted to supply each H-bridge cell. If the amplitude of all sources is equal, then the inverter is called symmetrical; otherwise, if at least one of the sources presents different amplitude, then it will be called asymmetrical. The second classification labels the multilevel inverter whether hybrid or not. If the converter is implemented with different semiconductor device technologies, different nature of DC sources (fuel cells, batteries, and supercapacitors) and/or if it presents a hybrid modulation strategy, then it is classified as hybrid [13-15]. This structure greatly simplifies the converter complexity.

The proposed control algorithm eliminates the need of additional isolated DC sources. The control strategy regulates the DC link voltages of capacitors connected to the smallest voltages of a two-cell 7-level cascaded $\mathrm{H}$-bridge inverter [16]. Specifically and in comparison to previous works $[17,18]$, the proposed control does not use an angle for capacitor voltage regulation but a comparison voltage level. This will facilitate a DSP implementation.

The carried out simulations and experiments validate the voltage control strategy and confirm the high dynamic performance of the proposed method, presenting very low torque ripple.

\section{Multilevel Inverter Topology}

The power circuit of the cascaded H-bridge multilevel inverter is illustrated in Figure 1. The inverter is composed by the series connection of power cells, each one containing an $\mathrm{H}$-bridge inverter and an isolated DC source. In the particular case of asymmetric inverters these sources are not equal $\left(V_{1}>V_{2}\right)$. The asymmetry of the input voltages can reduce or, when properly designed, eliminate redundant output levels, maximizing the number of different levels generated by the inverter. Therefore, this topology can achieve the same output voltage quality with less number of semiconductors, space, costs, and internal fault probability than the symmetric fed topology.

A particular cell $i$ can generate three voltage levels $\left(+V_{i}, 0,-V_{i}\right)$. The total inverter output voltage for a particular phase $j$ is then defined by

$$
v_{i N}=\sum_{j=1}^{m} v_{i j}=\sum_{j=1}^{m} V_{j}\left(S_{j 1}-S_{j 2}\right), \quad i \in\{a, b, c\},
$$

where $v_{i N}$ is the total output voltage of phase $i$ (resp., the neutral of the inverter $N$ ), the output voltage of cell of phase, and the switching state associated to cell.

It should be noticed how the output voltage of one cell is defined by one of the four binary combinations of the switching state, with " 1 " and " 0 " representing the "On" and "Off" states of the corresponding switch, respectively.

The inverter generates different voltage levels (e.g., an inverter with $m=4$ cells can generate $\left(2^{m+1}-1=31\right)$ different voltage levels). When using three-phase systems, the number of different voltage vectors is given by $3 n_{l}\left(n_{l}-1\right)+1$, where $n_{l}$ is the number of levels. For example, for the $m=4$ case with 31 levels there are 2791 different voltage vectors.

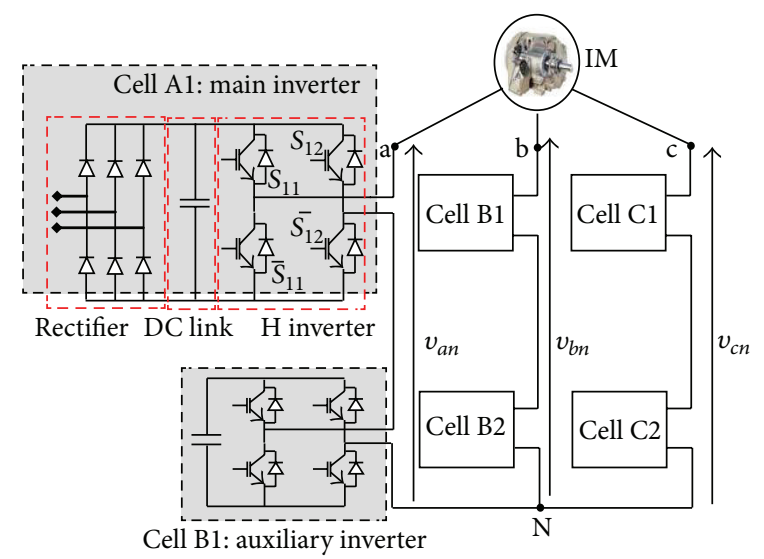

FIGURE 1: Hybrid cascaded multilevel converter topology.

TABLE 1: 7-Level asymmetric cascaded inverter switching states.

\begin{tabular}{cccccccc}
\hline & & Cell 1 & & \multicolumn{3}{c}{ Cell 2} & Total \\
& $S_{11}$ & $S_{12}$ & $v_{a 1}$ & $S_{21}$ & $S_{22}$ & $v_{a 2}$ & $v_{a N}$ \\
\hline 1 & 1 & 0 & $3 v_{\mathrm{DC}}$ & 0 & 0 & 0 & $3 v_{\mathrm{DC}}$ \\
2 & 1 & 0 & $3 v_{\mathrm{DC}}$ & 0 & 1 & $-v_{\mathrm{DC}}$ & $2 v_{\mathrm{DC}}$ \\
3 & 0 & 0 & 0 & 1 & 0 & $v_{\mathrm{DC}}$ & $v_{\mathrm{DC}}$ \\
4 & 0 & 0 & 0 & 0 & 0 & 0 & 0 \\
5 & 0 & 0 & 0 & 0 & 1 & $-v_{\mathrm{DC}}$ & $-v_{\mathrm{DC}}$ \\
6 & 0 & 1 & $-3 v_{\mathrm{DC}}$ & 1 & 0 & $v_{\mathrm{DC}}$ & $-2 v_{\mathrm{DC}}$ \\
\hline 7 & 0 & 1 & $-3 v_{\mathrm{DC}}$ & 0 & 0 & 0 & $-3 v_{\mathrm{DC}}$ \\
\hline
\end{tabular}

Table 1 summarizes the output levels for an asymmetric 7level inverter using only $m=2$ cells per phase (only phase voltage is given). An example of the voltage waveform for an asymmetric 7-level inverter is illustrated by Figure 2 .

\section{DTC-PWM Control}

3.1. DTC Basic Principles. The stator voltage space vector $\left(v_{s}\right)$ of an induction motor is related to the stator flux vector $\psi_{s}$ in a stator fixed coordinate system by

$$
v_{s}=R_{s} i_{s}+\frac{d \psi_{s}}{d t} .
$$

Neglecting the voltage drop in the stator resistance $R_{s}$, the stator flux vector is the time integral of the stator voltage vector. Hence, for a small sampling period $T_{s}$, (2) can be expressed by

$$
\Delta \psi_{s} \approx v_{s} T_{s} .
$$

On the other hand, the motor torque is related to the stator and rotor fluxes by

$$
T_{e}=\frac{3}{2} p \frac{k}{\sigma L_{s}}\left|\psi_{s}\right|\left|\psi_{r}\right| \sin (\delta),
$$

where $k=L_{m} / L_{s}$. If both flux magnitudes are kept constant in (4), the torque can be controlled directly by changing 

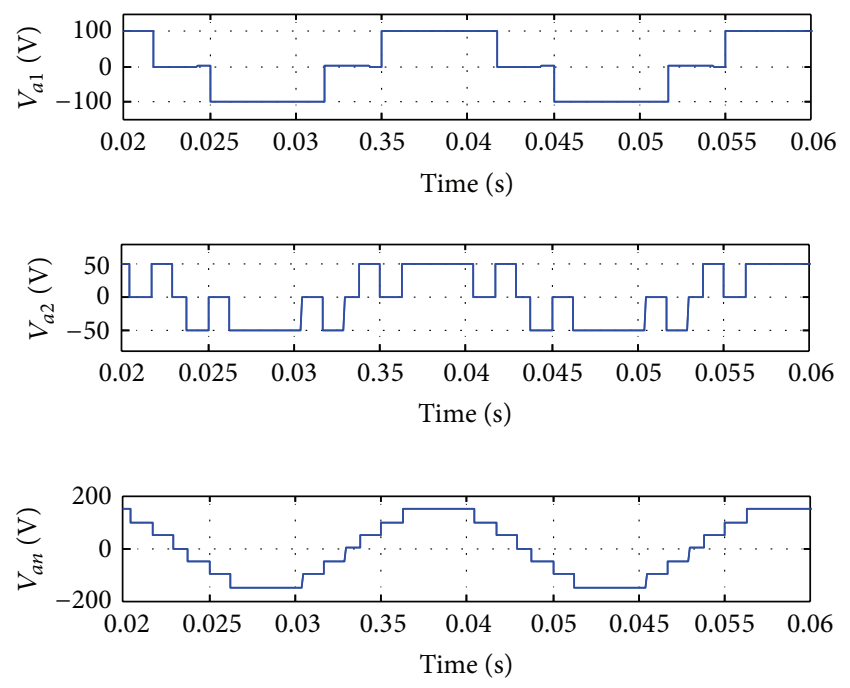

Figure 2: Asymmetric multilevel inverter with 7-level output voltage synthesis.

the load angle. This can be easily achieved, since variations in the stator flux vector change the load angle due to slower rotor flux dynamics.

Considering (3) and (4) it follows that the stator voltage vector can be used to manipulate the load angle and consequently to control the torque.

3.2. Flux and Torque Control by Load Angle Tracking. In traditional DTC, the influence over the load angle of each voltage vector generated by the inverter is determined and stored in a lookup table, according to the stator flux position in the complex plane. This is difficult to extend for multilevel inverter fed drives, where the complexity increases in huge proportions in relation to the levels generated by the inverter. Therefore, it is easier to look at the problem in a different way: the torque error can be used to generate a reference load angle $\delta^{*}$ necessary to correct the torque behavior. Then the desired load angle can be used to compute the exact voltage vector that will produce the necessary flux variation $\Delta \psi_{s}$. This principle is illustrated in Figure 3. Note that once provided the reference load angle $\delta^{*}$, the reference stator flux vector $\psi_{s}^{*}$ can be computed by

$$
\psi_{s}^{*}=\left|\psi_{s}^{*}\right| \cos \left(\delta^{*}+\theta_{r}\right)+j\left|\psi_{s}^{*}\right| \sin \left(\delta^{*}+\theta_{r}\right),
$$

where $\left|\psi_{s}^{*}\right|$ is the fixed stator flux amplitude reference, and $\theta_{r}$ is the rotor flux vector angle. Note that $\left(\delta^{*}+\theta_{r}\right)$ corresponds to the reference stator flux vector angle $\theta_{s}^{*}$. by

Then the desired stator voltage vector $v_{s}^{*}$ can be obtained

$$
v_{s} \approx \frac{\Delta \psi_{s}}{T_{s}}=\frac{\psi_{s}^{*}-\psi_{s}}{T_{s}}
$$

Finally $v_{s}^{*}$ has to be generated by the inverter. This is commonly performed with PWM or SVM for 2-level

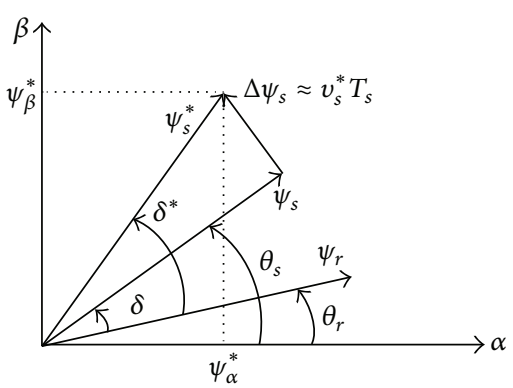

FIGURE 3: Stator voltage vector influence over the stator flux vector.

inverters [19]. The use of a multilevel inverter will reduce the torque ripple amplitude due to the reduction of the rate of change of the common-mode voltage (number of step variations in a fixed time span), and, in this case, using the hybrid modulation method [20], a fixed-frequency output voltage will be obtained concentrating the voltage spectrum around the carrier frequency of the small power cell. Hence the most important drawbacks of traditional DTC are corrected. A simplified control diagram of the proposed strategy is shown in Figure 4. The outer speed control loop is omitted.

\section{Hybrid Modulation Strategy}

The hybrid modulation is specially conceived for the asymmetric multilevel $\mathrm{H}$-bridge inverter structure [14].

The basic idea is to take advantage of the different power rates among the cells to reduce switching losses and improve the converter efficiency. From Figure 5 it can be seen that the inverter generates a rectangular waveform, which is at the same frequency of the reference (turn-on and -off only one time during a half reference cycle). The remaining of the output voltage, second trace in Figure 5, is synthesized by the auxiliary inverter at high switching frequency (with sinusoidal PWM). This completes the generation of a multilevel stepped waveform with a high-frequency component (similar to a multicarrier-based PWM), but with the difference that fewer switching losses are produced to achieve it. Typical output waveform of the inverter using this modulation is shown in the third trace of Figure 5. Note that the output has 7 different voltage levels given by all the possible combinations of the series connection of $\left(+V_{\mathrm{DC}}, 0,-V_{\mathrm{DC}}\right)$ and $\left(+2 V_{\mathrm{DC}}, 0,-2 V_{\mathrm{DC}}\right)$.

\section{Capacitor Voltage Control}

Capacitor voltage control in the auxiliary inverter is a challenging task $[14,21]$. The proposed control method is based on a hybrid modulation that consists of adjusting the main inverter turn-on. This indeed corresponds to adjusting the active and reactive powers that the main inverter injects to the load (if $\alpha$ is chosen to be exactly $18^{\circ}$, the main inverter injects only active power). By shifting the voltage waveform synthesized by the main inverter (Figure 6), one could also inject some reactive power, which 


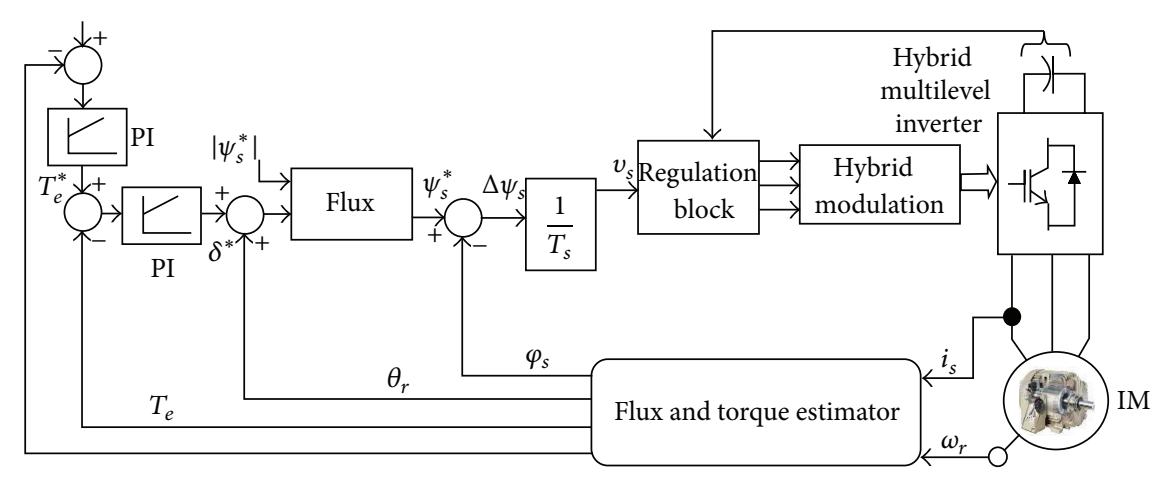

FIGURE 4: Hybrid multilevel inverter-fed DTC motor drive with a single DC source.
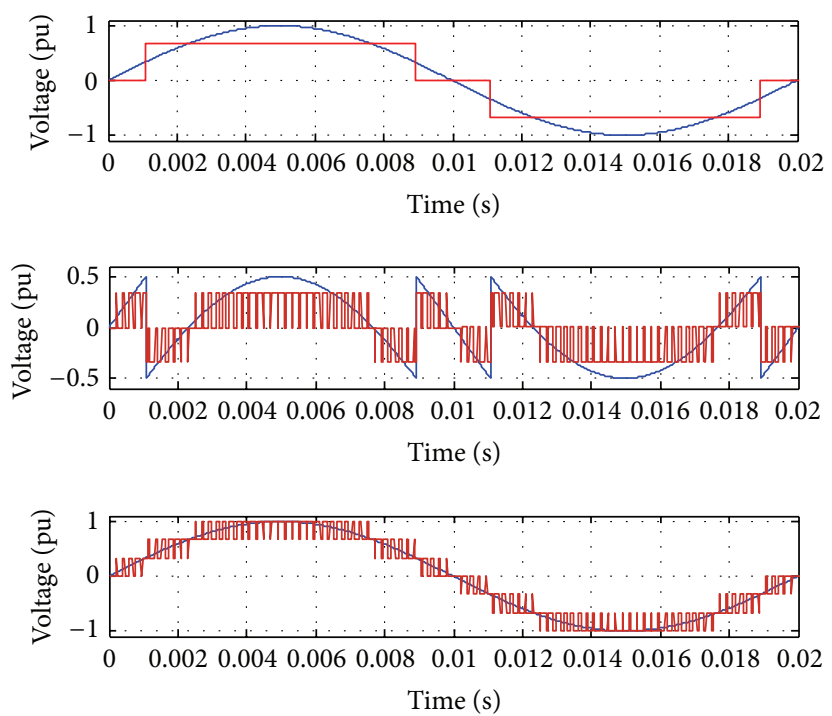

FIGURE 5: Desired output, auxiliary and main inverter voltage waveforms.

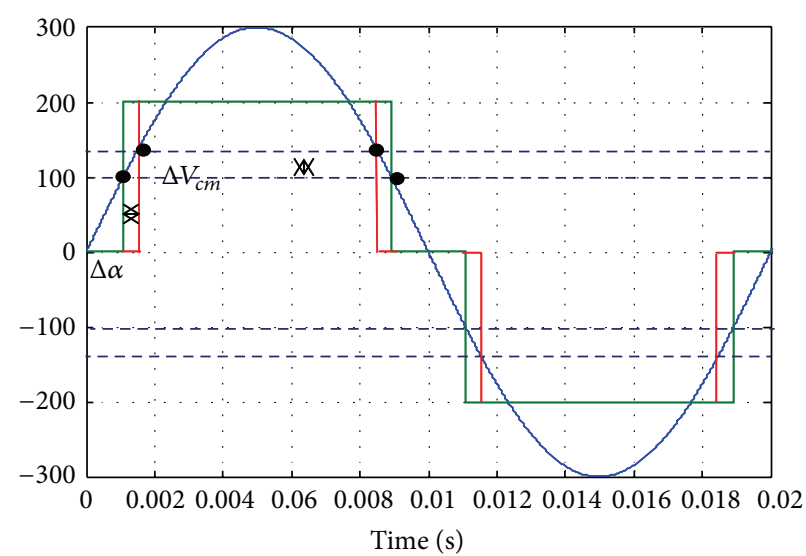

FIGURE 6: Variation of the main inverter conduction angle by $V_{\mathrm{cm}}$ variation.

can be used to charge or discharge the auxiliary inverter capacitor.

Therefore, the proposed algorithm, illustrated by Figure 7, regulates the capacitor voltage by an appropriate adjustment of $\Delta \alpha$ which is given by the PI regulator and acts directly on the variation of the comparison level $V_{\mathrm{cm}}$ that controls the main inverter turn-on and -off. The closed loop regulation for each phase is done by measuring the capacitor 


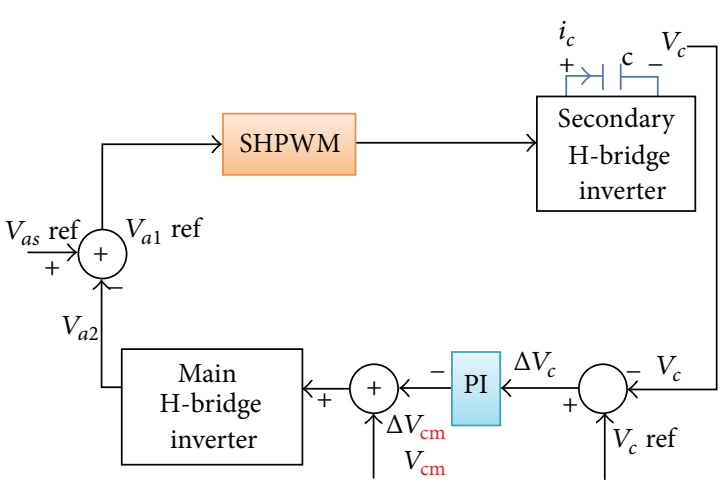

FIGURE 7: Closed-loop control of the capacitor voltages.

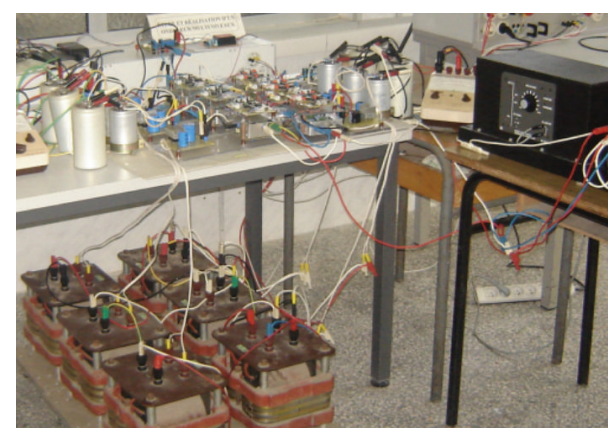

FIGURE 8: 7-level single DC source cascaded H-bridge multilevel inverter.

voltage. From the capacitors voltage error, the PI regulator gives directly the necessary $\Delta V_{\mathrm{cm}}$ to be added to the initial comparison level which leads to changing the conduction angle $\alpha$ of the main inverter that allows the secondary inverter capacitor charging.

\section{Experimental and Simulations Results}

6.1. Hybrid Modulation Strategy Implementation. The abovediscussed hybrid modulation strategy has been experimentally implemented (Figure 8). The proposed hybrid modulation strategy main results are illustrated by Figure 9 . As abovementioned, the inverter generates a rectangular waveform, which is at the same frequency of the reference (Figure 9(a)). The remaining of the output voltage is synthesized by the auxiliary inverter at high switching frequency with sinusoidal PWM (Figure 9(b)). Figure 9(c) shows the typical output waveform of the 7-level inverter under hybrid modulation.

6.2. Simulation Tests on an Induction Motor-Based EV Propulsion. To evaluate the dynamic performances of the proposed control strategy, numerical simulations have been carried out on an EV propelled by an induction motor supplied with 7-level single DC source cascaded multilevel inverter (Figure 4).

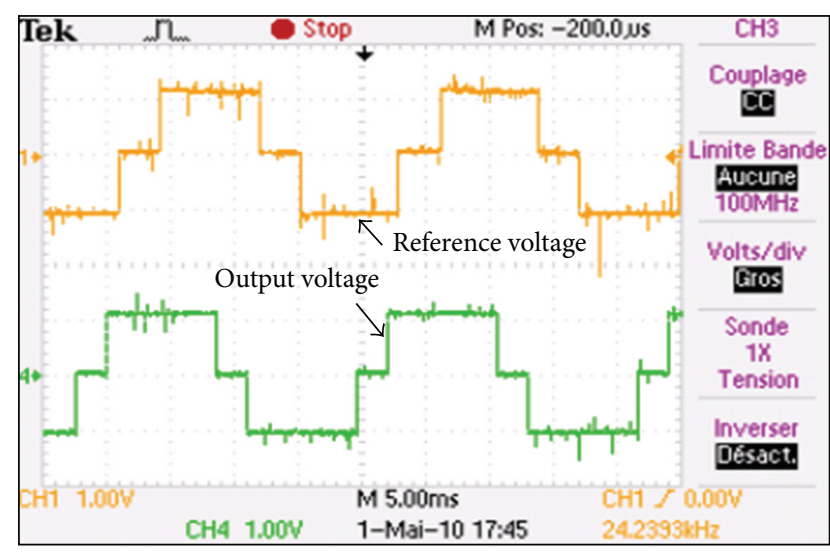

(a) Main H-bridge inverter voltages

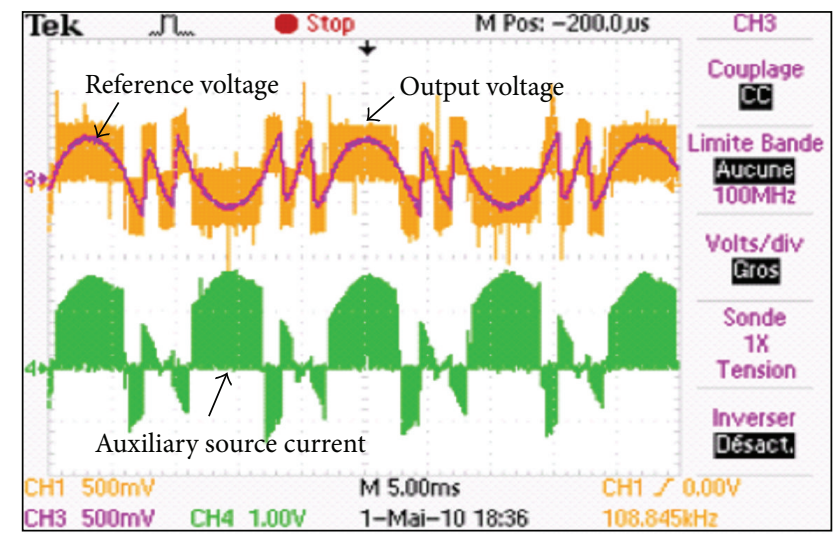

(b) Secondary H-bridge inverter voltages and auxiliary source (feeding the H-bridge) current

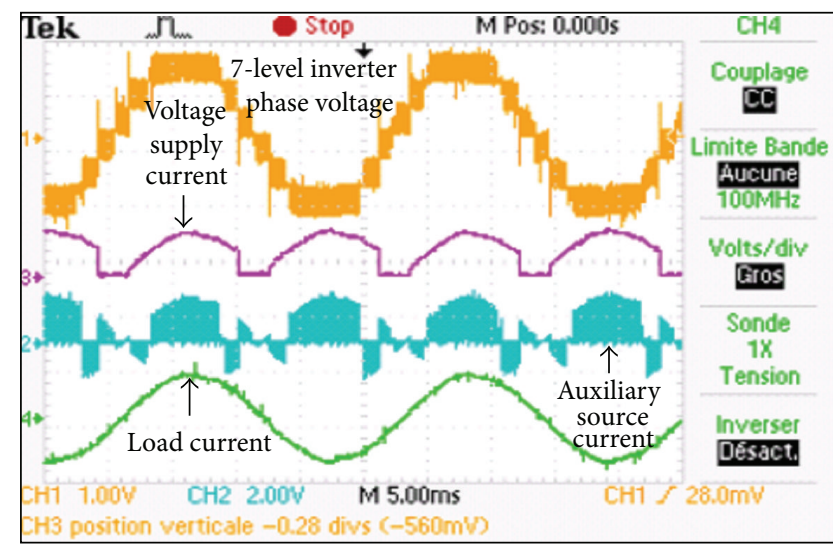

(c) The main outputs

FIGURE 9: Desired output, main, auxiliary, and inverter voltage and current waveforms of the realized 7-level inverter under hybrid modulation.

Simulations were done using the standardized ECE-15 and EUDC driving cycle [22]. The achieved performances are illustrated by Figures 10 to 15 .

The simulation results show that the speed reference required by the driver is well-tracked as shown by Figure 10. One can see that the induction motor developed torque presents fewer ripples compared to a traditional DTC 


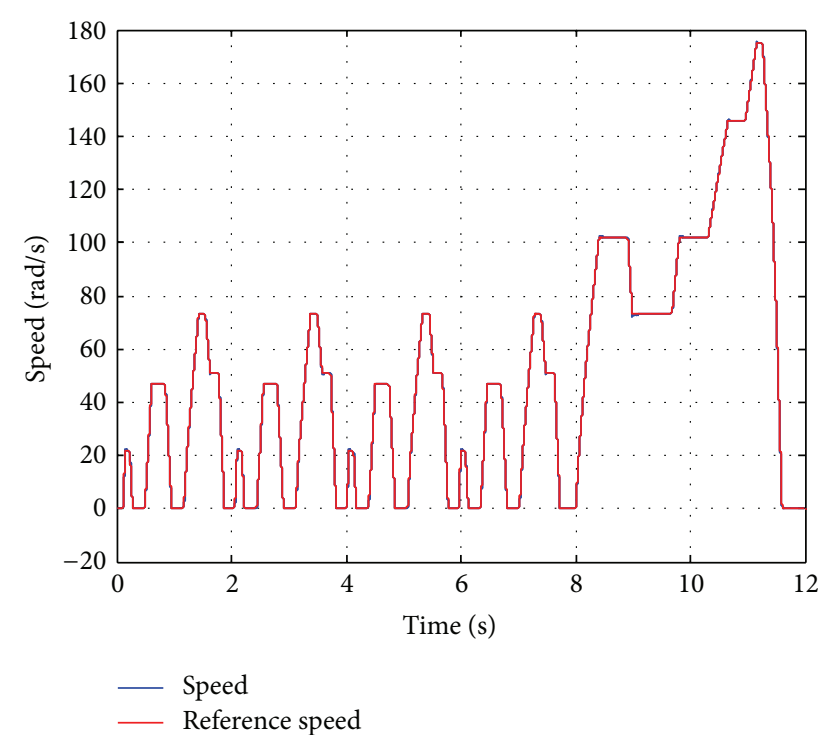

FIGURE 10: Speed with the ECE-15 + EUDC driving cycle.

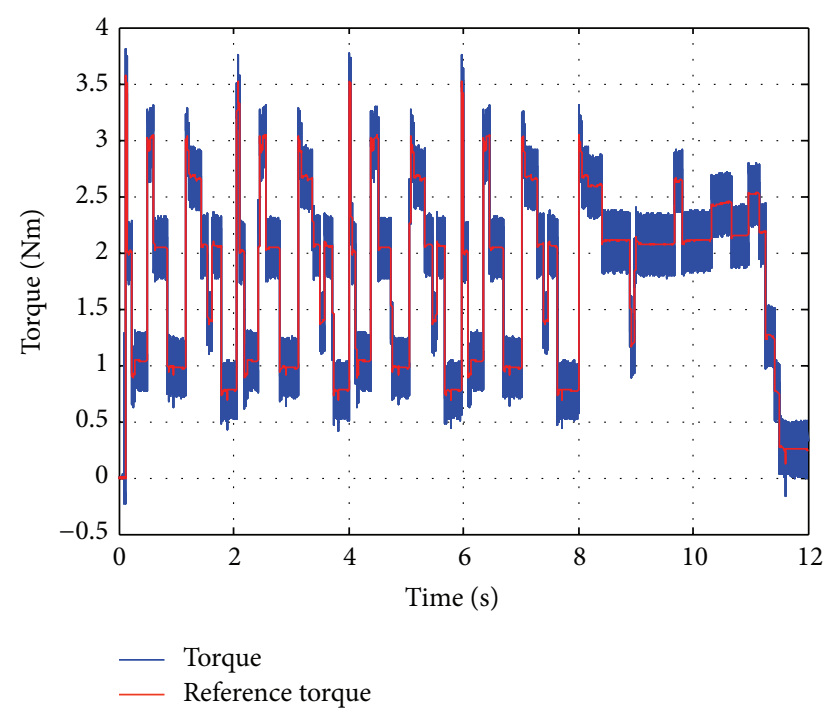

FIGURE 11: Reference and developed torques.

(Figure 11). This is due to the quality of the voltage supplying the inverter (Figure 12). Consequently, the stator currents are almost sinusoidal (Figure 13) and better dynamics are obtained; operating practically with constant flux (Figure 14).

Figure 15 shows the capacitor voltages waveforms which supply each auxiliary H-bridge of the three phase hybrid multilevel inverter. One can notice the oscillations around the reference. Moreover, these voltages are quiet identical. However, their difference becomes very large when there is a significant acceleration or deceleration requested by the driver. Indeed, in these cases, different amounts of energy are required due to the induction motor operating point fast variation.

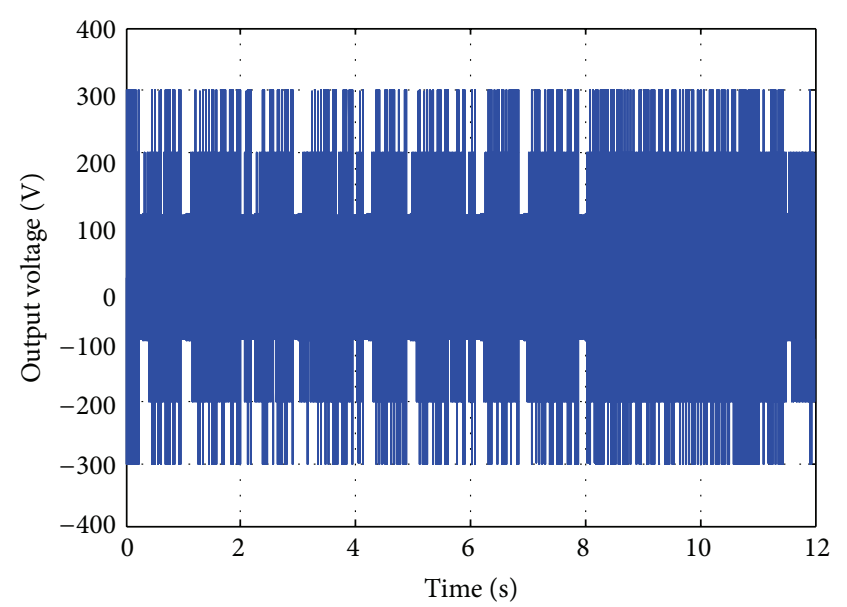

FIGURE 12: Output voltage waveform.

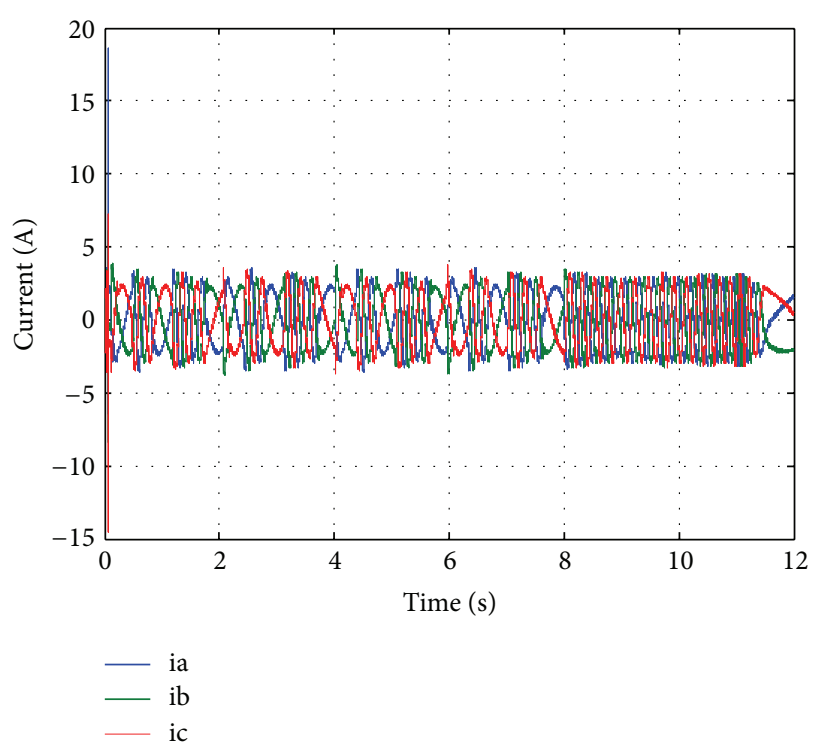

FIGURE 13: Stator currents waveforms.

The above-presented simulation results confirm that, independently of the requested speed and torque, the capacitor voltages are controlled and the validity of the proposed control approach is proven.

\section{Conclusion}

In this paper a control strategy has been proposed for a hybrid cascaded multilevel inverter with a modified DTC scheme intended for induction motor-based EV propulsion. In this case, the main inverter uses a single DC voltage source, and the auxiliary inverter capacitor voltages are controlled in each phase. In addition, DTC-PWM allows the operation with a fixed switching frequency, the reduction in the torque ripple without output filter, and high-performance torque and flux control.

The proposed control method simplifies the DTC application in embedded systems by reducing the inverter cost 


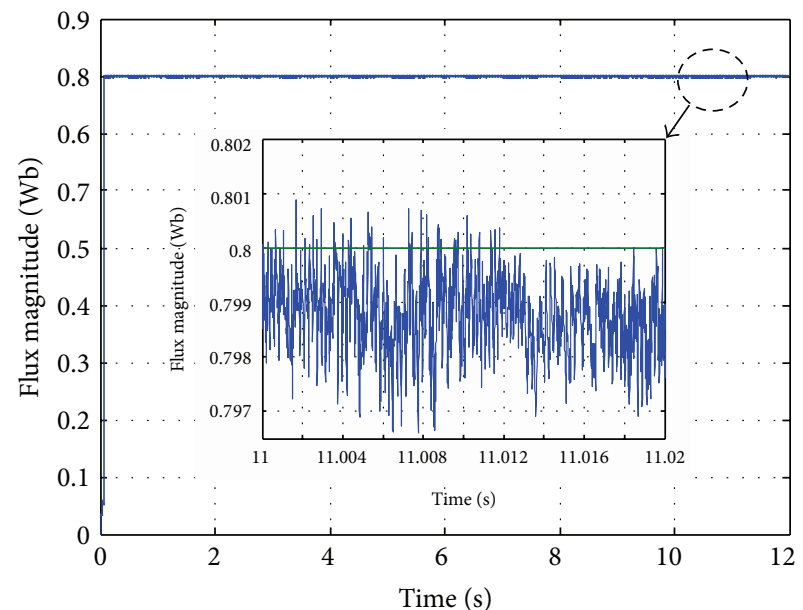

(a) Flux magnitude

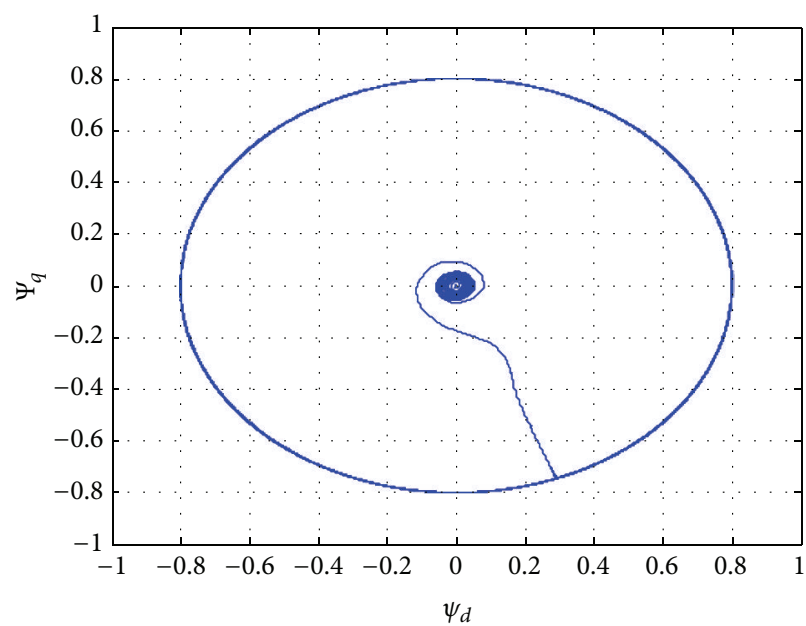

(b) Flux locus

FIGURE 14: Magnitude and locus of the stator flux in the DTC-PWM.

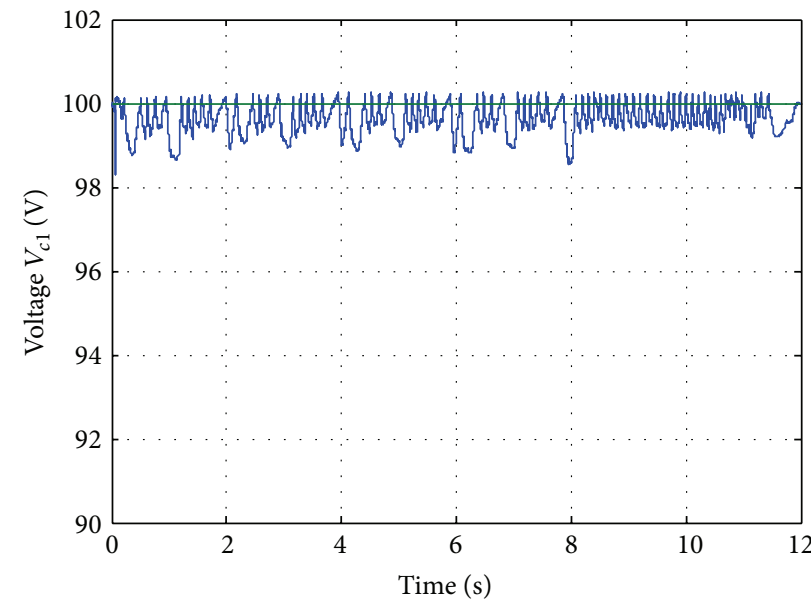

(a) Phase a

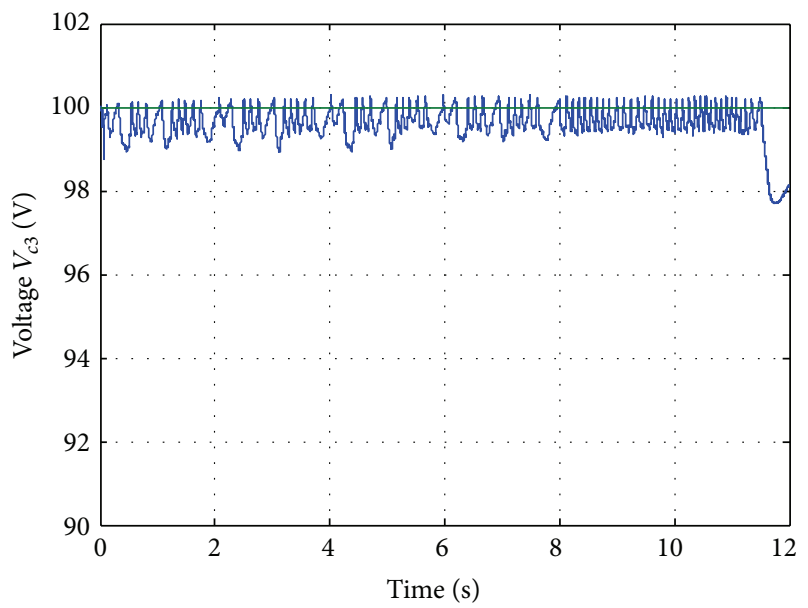

(c) Phase c

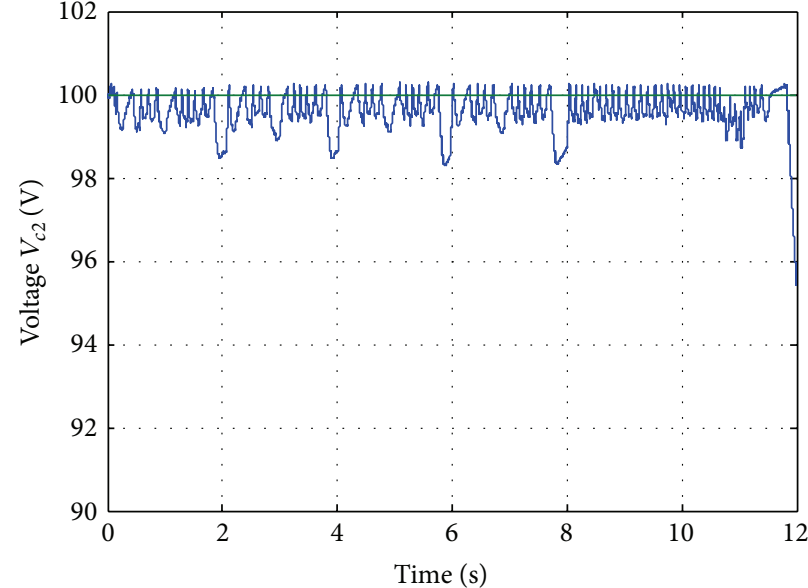

(b) Phase b
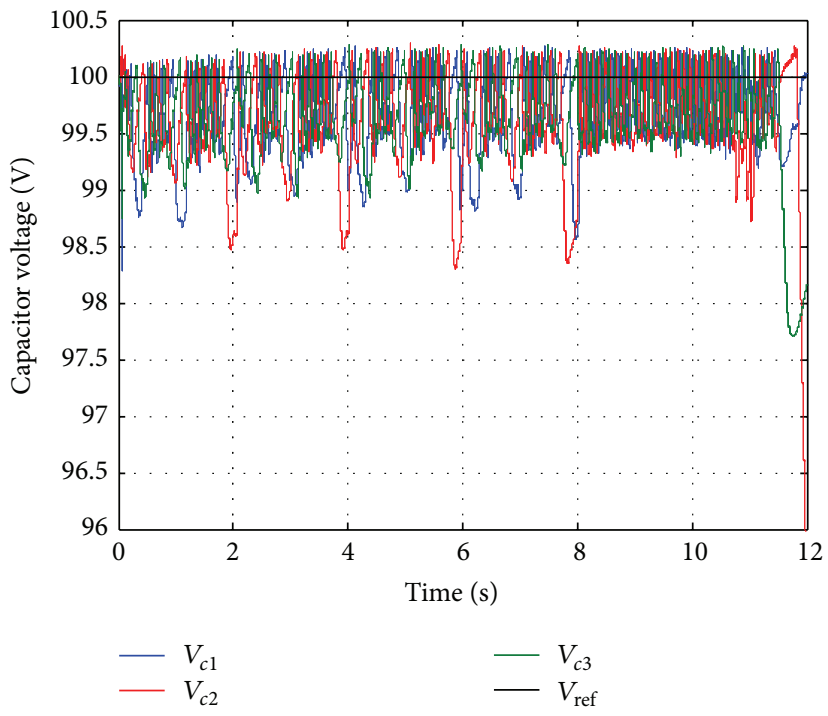

(d) Capacitor voltage comparison zoom

FIGURE 15: Capacitor voltage waveforms. 
TABLE 2: Rated data of the simulated induction motor.

$1 \mathrm{~kW}, 50 \mathrm{~Hz}, 400 / 230 \mathrm{~V}, 3.4 / 5.9 \mathrm{~A}, 1420 \mathrm{rpm}$

$R_{s}=4.67 \Omega, R_{r}=8 \Omega, L_{s}=L_{r}=0.347 \mathrm{H}, L_{m}=0.366 \mathrm{H}$

$J=0.06 \mathrm{~kg} \cdot \mathrm{m}^{2}, \beta=0.042 \mathrm{Nm} \cdot \mathrm{sec}$

and complexity (by decreasing the semiconductor and the source numbers). Moreover, there is no need for hysteresis comparators and lookup tables. All these key features make the proposed control approach very attractive for embedded systems such as automotive applications.

\section{Appendix}

See Table 2.

\section{Nomenclature}

EV: $\quad$ Electric vehicle

DTC: Direct torque control

FOC: Field-oriented control

PWM: Pulse width modulation

SVM: Space vector modulation

$s,(r)$ Stator (rotor) index

$v(i)$ Voltage (current)

$\psi: \quad$ Flux

$T_{e}$ : Electromagnetic torque

$R: \quad$ Resistance

$L\left(L_{m}\right)$ : Inductance (mutual inductance)

$\sigma: \quad$ Leakage coefficient, $\sigma=1-L_{m}^{2} / L_{s} L_{r}$

$\delta$ : $\quad$ Load angle

$p: \quad$ Pole pair number.

\section{References}

[1] C. C. Chan, A. Bouscayrol, and K. Chen, "Electric, hybrid and fuel cell vehicles: architectures and modelling," IEEE Transactions on Vehicular Technology, vol. 59, no. 2, pp. 589-598, 2010.

[2] M. Zeraoulia, M. E. H. Benbouzid, and D. Diallo, "Electric motor drive selection issues for HEV propulsion systems: a comparative study," IEEE Transactions on Vehicular Technology, vol. 55, no. 6, pp. 1756-1764, 2006.

[3] D. O. Neacsu and K. Rajashekara, "Comparative analysis of torque-controlled IM drives with applications in electric and hybrid vehicles," IEEE Transactions on Power Electronics, vol. 16, no. 2, pp. 240-247, 2001.

[4] A. Haddoun, M. E. H. Benbouzid, D. Diallo, R. Abdessemed, J. Ghouili, and K. Srairi, "A loss-minimization DTC scheme for EV induction motors," IEEE Transactions on Vehicular Technology, vol. 56, no. 1, pp. 81-88, 2007.

[5] D. Casadei, G. Serra, A. Tani, L. Zarri, and F. Profumo, "Performance analysis of a speed-sensorless induction motor drive based on a constant switching-frequency DTC scheme," IEEE Transactions on Industry Applications, vol. 39, no. 2, pp. 476-484, 2003.

[6] C. A. Martins, X. Roboam, T. A. Meynard, and A. S. Carvalho, "Switching frequency imposition and ripple reduction in DTC drives by using a multilevel converter," IEEE Transactions on Power Electronics, vol. 17, no. 2, pp. 286-297, 2002.
[7] J. Rodríguez, J. Pontt, S. Kouro, and P. Correa, "Direct torque control with imposed switching frequency in an 11-level cascaded inverter," IEEE Transactions on Industrial Electronics, vol. 51, no. 4, pp. 827-833, 2004.

[8] G. S. Buja and M. P. Kazmierkowski, "Direct torque control of PWM inverter-fed AC motors-a survey," IEEE Transactions on Industrial Electronics, vol. 51, no. 4, pp. 744-757, 2004.

[9] M. Malinowski, K. Gopakumar, J. Rodriguez, and M. A. Perez, "A survey on cascaded multilevel inverters," IEEE Transactions on Industrial Electronics, vol. 57, no. 7, pp. 2197-2206, 2010.

[10] P. Cortes, A. Wilson, S. Kouro, J. Rodriguez, and H. AbuRub, "Model predictive control of multilevel cascaded H-bridge inverters," IEEE Transactions on Industrial Electronics, vol. 57, no. 8, pp. 2691-2699, 2010.

[11] J. Dixon, J. Pereda, C. Castillo, and S. Bosch, "Asymmetrical multilevel inverter for traction drives using only one DC supply," IEEE Transactions on Vehicular Technology, vol. 59, no. 8, pp. 3736-3743, 2010.

[12] J. Rodriguez, J.-S. Lai, and F. Z. Peng, "Multilevel inverters: a survey of topologies, controls and applications," IEEE Transactions on Industrial Electronics, vol. 49, no. 4, pp. 724-738, 2002.

[13] F. Khoucha, S. M. Lagoun, K. Marouani, A. Kheloui, and M. E. H. Benbouzid, "Hybrid cascaded H-bridge multilevel-inverter induction-motor-drive direct torque control for automotive applications," IEEE Transactions on Industrial Electronics, vol. 57, no. 3, pp. 892-899, 2010.

[14] Z. Du, L. M. Tolbert, B. Ozpineci, and J. N. Chiasson, "Fundamental frequency switching strategies of a seven-level hybrid cascaded H-bridge multilevel inverter," IEEE Transactions on Power Electronics, vol. 24, no. 1, pp. 24-22, 2009.

[15] C. Rech and J. R. Pinheiro, "Impact of hybrid multilevel modulation strategies on input and output harmonic performances," IEEE Transactions on Power Electronics, vol. 22, no. 3, pp. 967977, 2007.

[16] F. Khoucha, A. Ales, A. Khoudiri, K. Marouani, M. E. H. Benbouzid, and A. Kheloui, "A 7-level single DC source cascaded H-bridge multilevel inverters control using hybrid modulation," in Proceedings of the 19th International Conference on Electrical Machines (ICEM '10), pp. 1-5, Rome, Italy, September 2010.

[17] J. Liao, K. Corzine, and M. Ferdowsi, "A new control method for single-DC-source cascaded H-bridge multilevel converters using phase-shift modulation," in Proceedings of the $23 \mathrm{rd}$ Annual IEEE Applied Power Electronics Conference and Exposition (APEC '08), pp. 886-890, Austin, Tex, USA, February 2008.

[18] S. Kouro, R. Bernai, H. Miranda, J. Rodríguez, and J. Pontt, "Direct torque control with reduced switching losses for asymmetric multilevel inverter fed induction motor drives," in Proceedings of the 41st IEEE IAS Annual Meeting, pp. 2441-2446, Tampa, Fla, USA, October 2006.

[19] D. Casadei, F. Profumo, G. Serra, and A. Tani, "FOC and DTC: two viable schemes for induction motors torque control," IEEE Transactions on Power Electronics, vol. 17, no. 5, pp. 779-787, 2002.

[20] M. Veenstra and A. Rufer, "Control of a hybrid asymmetric multilevel inverter for competitive medium-voltage industrial drives," IEEE Transactions on Industry Applications, vol. 41, no. 2, pp. 655-664, 2005.

[21] J. Liao, K. Wan, and M. Ferdowsi, "Cascaded H-bridge multilevel inverters-a reexamination," in Proceedings of the IEEE Vehicle Power and Propulsion Conference (VPPC '07), pp. 203207, Arlington, Va, USA, September 2007. 
[22] A. Haddoun, M. E. H. Benbouzid, D. Diallo, R. Abdessemed, J. Ghouili, and K. Srairi, "Modeling, analysis, and neural network control of an EV electrical differential," IEEE Transactions on Industrial Electronics, vol. 55, no. 6, pp. 2286-2294, 2008. 

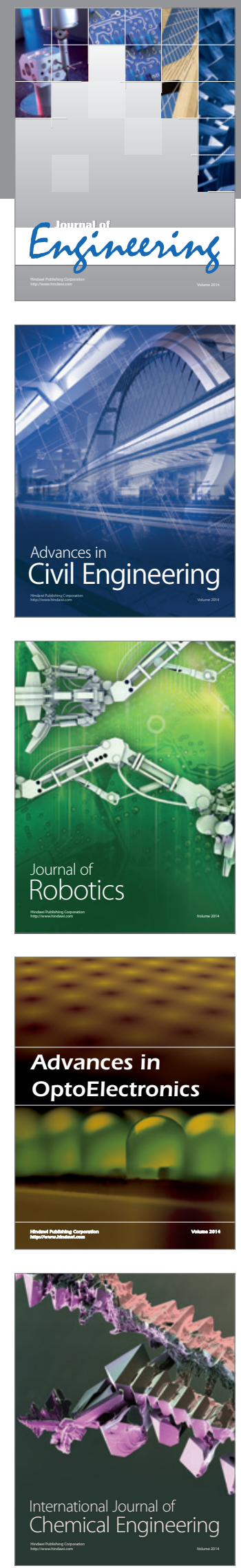

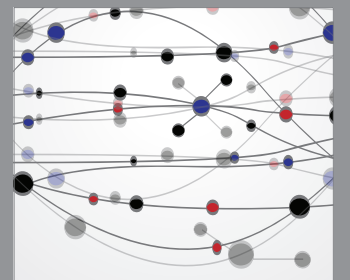

The Scientific World Journal
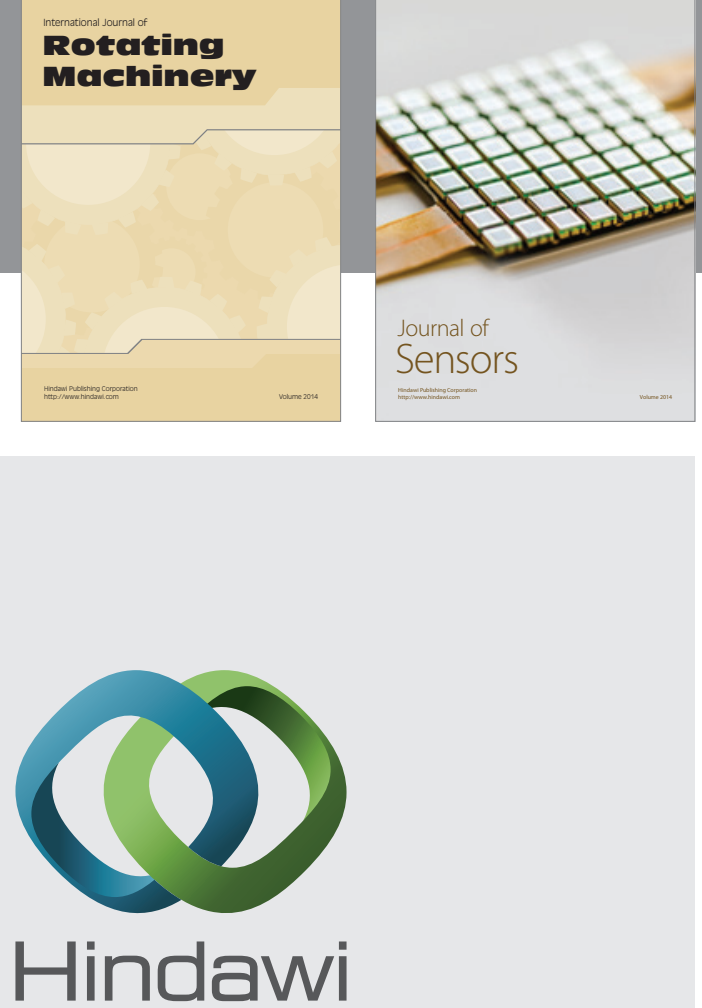

Submit your manuscripts at http://www.hindawi.com
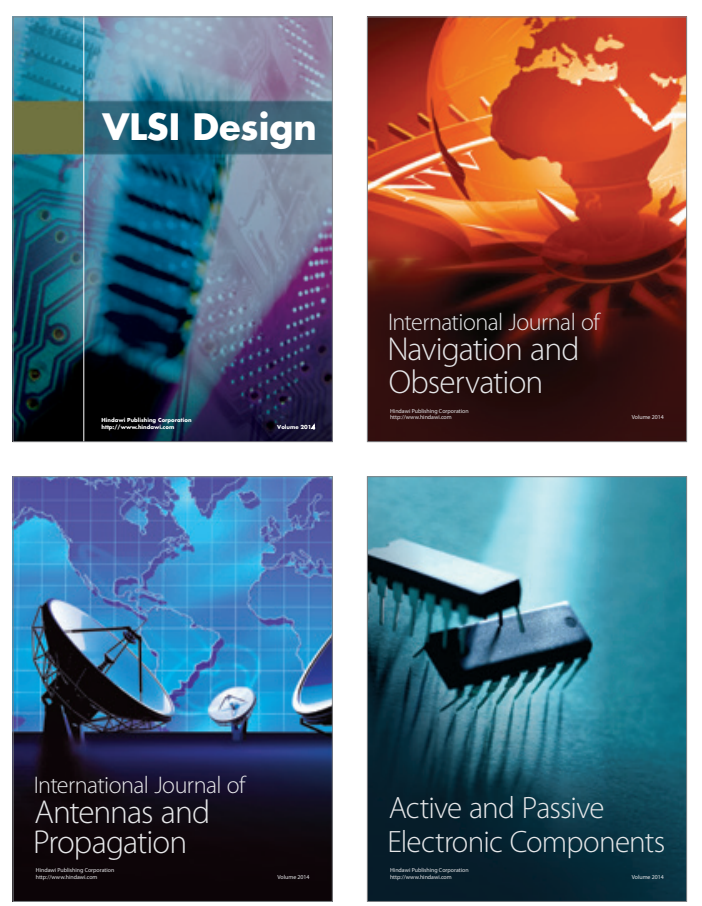
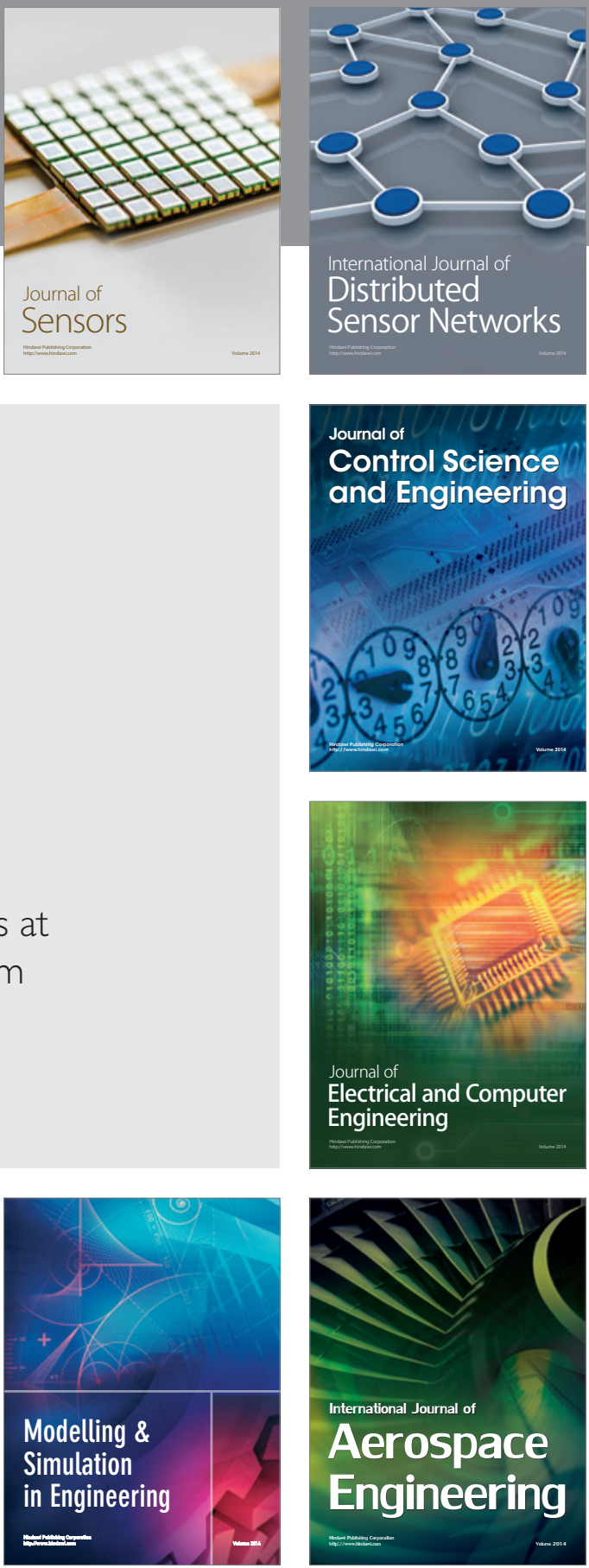

Journal of

Control Science

and Engineering
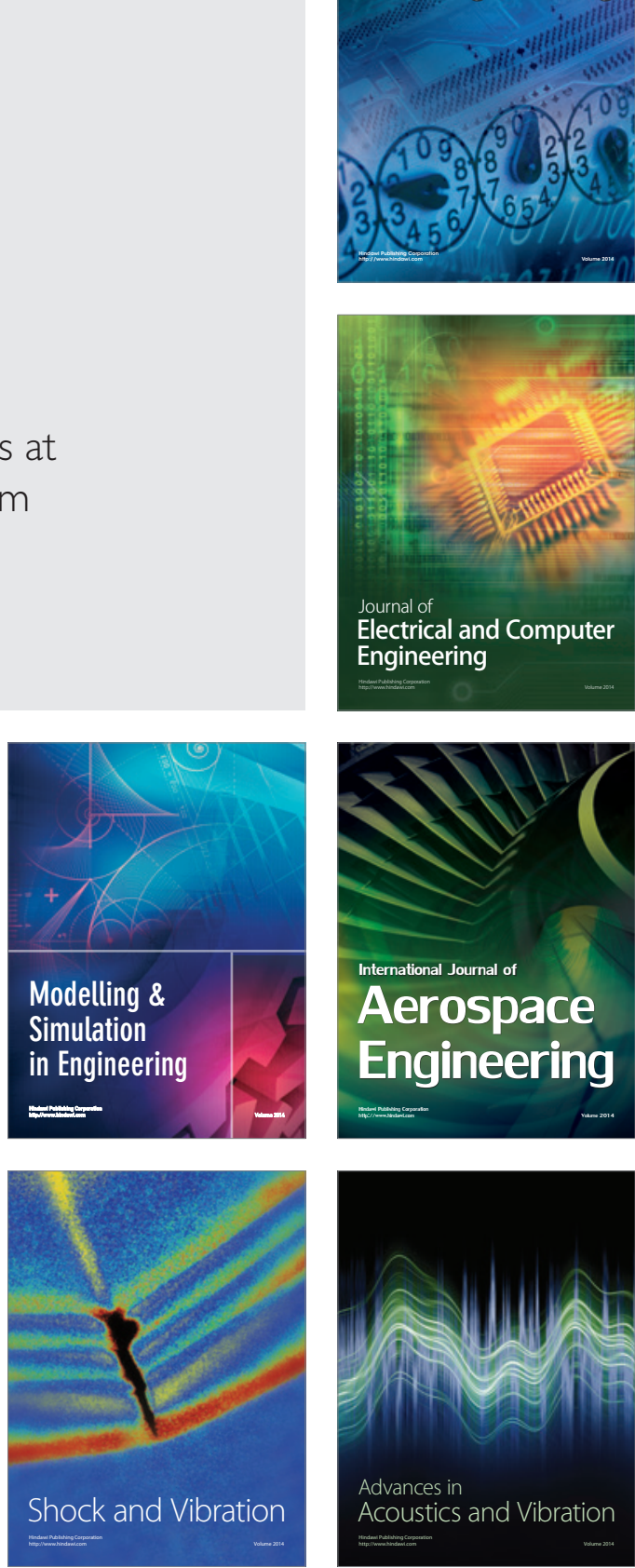